\title{
The filament event near the Cenomanian-Turonian boundary in Tunisia: filament origin and environmental signification
}

\author{
Mohamed Hédi NEGRA ${ }^{1}$, Mohamed FAouZi ZAGRARNI², Amine HANINI ${ }^{1}$ \\ and ANDRÉ STRASSER ${ }^{3}$
}

Key-words. - Tunisia, Cenomanian-Turonian boundary, Black shales, Filaments, Storm deposits

Abstract. - Near the Cenomanian-Turonian boundary, the filament event corresponds to the massive occurrence of thin elongate shells, probably bivalves which constitute, in the Bahloul Formation, about $40 \%$ of allochems. This biosedimentary event was described in several areas, such as in Tunisia, Algeria, Morocco, North America, Oman and Tibet. In Tunisia, filaments are well represented within well laminated black shales constituting the Bahloul Formation, late Cenomanian - early Turonian in age. These black shales were deposited under anoxic conditions developed in an outer ramp environment. Filaments are particularly abundant in the upper part of the Bahloul Formation, which is topped by a condensation level exhibiting encrusted ammonites associated with frequent burrows, and phosphatic and glauconitic grains. In terms of depositional environments, the filament concentrations announce an evolution towards "normal"-marine conditions, which followed the anoxic conditions favouring black-shale formation. This trend coincided with a deepening that led to maximum flooding at the condensation surface. The petrographic study of samples taken along a N-S transect shows a clear evolution of filament structures from distal to proximal ramp. Limestones deposited in the outer ramp environment mainly contain well preserved "pelagic" bivalve shells showing a thin-shelled structure composed of elongated filaments. Laterally, toward the proximal ramp, the bivalve shells are progressively disintegrated, the filaments being arranged parallel to bedding. In an even more proximal setting, filaments appear finer, highly fragmented and arranged without preferential orientation. The Cenomanian-Turonian "pelagic" bivalves thus probably lived in an outer ramp environment and their thin shells disintegrated progressively into filaments. This happened during high energy conditions generated by storms.

The filament event, which is associated to other bio-events expressed by the extinction and the first occurrence of some pelagic species, could be used to establish local to global correlations.

When the ammonite Watinoceras, the main early Turonian marker, is rare or absent, the filament-rich facies could indicate the proximity of the Cenomanian-Turonian boundary.

At a global scale, the filament event illustrates a sea-level rise in relation with eustatic and climatic changes. The maximum flooding of this transgressive event was identified in several localities and dated about 93 Ma. The very high sea-level conditions are favourable to accumulation and preservation of organic-rich facies such as black shales, which illustrate the anoxic event OAE2.

The abundance of filaments near the Cenomanian-Turonian boundary is an indicator of high organic productivity following a climatic change to warmer conditions. The latter have clearly influenced oceanic water-masses circulation, water column stratification and nutrient partitioning.

\section{L'événement “à filaments” à la limite Cénomanien - Turonien en Tunisie : origine et milieux de genèse des filaments}

Mots-clés. - Tunisie, Limite Cénomanien-Turonien, Black shales, Filaments, Dépôts de tempête

Résumé. - A la limite Cénomanien-Turonien, l'évènement à filaments a été identifié à l'échelle mondiale. En Tunisie, les filaments sont bien représentés dans des calcaires noirs finement laminés, en plaquettes, constituant, la formation Bahloul d'âge cénomanien supérieur-turonien basal. Ces calcaires noirs sont déposés dans un environnement plus ou moins anoxique, inclus dans la partie distale d'une rampe. C'est préférentiellement dans la partie supérieure de la formation Bahloul que ces filaments deviennent particulièrement abondants. La limite supérieure de la formation Bahloul coïncide avec une surface de condensation intensément bioturbée et riche en ammonites. En termes de milieux de dépôt, l'abondance des filaments est l'expression d'une ouverture du milieu, faisant suite à une restriction accompagnée d'une anoxie ayant favorisé le dépôt des black shales.

Cette ouverture du milieu peut être liée à une transgression dont l'inondation maximale coïncide avec l'abondance des filaments. L'étude pétrographique de coupes sériées levées le long d'un profil plate-forme/bassin, montre une évolution de ces filaments en morphotypes distincts. En effet, les calcaires déposés dans un domaine de type rampe distale contiennent des coquilles de bivalves pélagiques parfaitement préservées, montrant une microstructure composée d'un assemblage de filaments jointifs, allongés et parallèles aux plans de stratification. Latéralement, vers la partie

1. University of Tunis El Manar, Tunis Faculty of Sciences, Tunisia. Hedi.Negra@fst.rnu.tn

1. University of Gabes, Institut Supérieur des Sciences et Techniques des Eaux, Tunisia. Zagrarni_m_f@yahoo.fr

3. University of Fribourg, Department of Geosciences, Switzerland. Andreas.strasser@unifr.ch 
proximale de la rampe, ces coquilles, qui sont progressivement fragmentées, montrent une microstructure partiellement dissociée en filaments calcitiques allongés. Dans une position encore plus proximale, la microstructure est plus dissociée, en filaments plus fins et désorientés. En somme, la genèse des filaments est due à une désintégration progressive de coquilles de bivalves pélagiques issus d'un milieu de type rampe externe. L'individualisation des filaments à partir de ces coquilles peut être liée à une énergie élevée du milieu probablement en rapport avec l'action de courants de tempête. La désintégration des coquilles de bivalves pélagiques en filaments qui serait provoquée au cours d'une élévation eustatique, prendrait son ampleur lors de la phase d'inondation maximale.

L'événement à filaments a une grande valeur chronostratigraphique puisqu'il se situe immédiatement en dessous de la limite Cénomanien-Turonien datée à 93,5 Ma. En l'absence de l'ammonite Watinoceras considérée comme marqueur du Turonien basal, les faciès à abondants filaments peuvent être utilisés comme indicateurs de la proximité de cette limite. D'un autre côté, l'événement à filaments s'intègre dans un contexte transgressif dont le maximun d'inondation marquée par une surface de condensation, se situe autour de $93 \mathrm{Ma}$.

Sur le plan séquentiel, l'élévation eustatique fait partie d'un cycle de premier ordre qui illustre un changement d'ordre climatique intéressant le milieu océanique. Les fortes expansions crustales, la genèse de rides océaniques, ainsi que les activités tectoniques et volcaniques ont eu comme conséquence un monde de type "greenhouse » marqué par des élévations eustatiques et un réchauffement des eaux océaniques dont l'ampleur se sent particulièrement à la base du Turonien.

A l'échelle des cycles eustatiques à plus haute fréquence (de troisième ordre), l'événement à filaments apparaît immédiatement en dessous de la limite Cénomanien-Turonien, tout près de la surface d'inondation maximale.

Cette élévation eustatique à la base du Turonien, qui est la plus marquée dans l'intervalle méso-cénozoïque, apparaît favorable au développement de conditions anoxiques particulièrement dans les masses d'eaux océaniques intermédiaires et profondes. Ces conditions sont également à l'origine d'une haute productivité organique qui serait en rapport avec un phénomène d'advection verticale des nutriments, liée à la stratification de la colonne d'eau ainsi qu'aux circulations océaniques. Elles sont également propices à l'accumulation et la préservation de la matière organique illustrant l'événement anoxique OAE2 qui est souvent marqué par une excursion positive de $\delta{ }^{13} \mathrm{C}$.

\section{INTRODUCTION}

Mass accumulations of thin bivalve shells ("filaments") occur in several distinct limestone and marly intervals throughout the Mesozoic Tethyan realm [e.g., Razgallah et al., 1994; Robaszynski et al., 1994; Maamouri et al., 1994; Molina et al., 1997; Accarie et al., 2000; Abdallah et al., 2000; Wan et al., 2003; Ettachfini and Andreu, 2004; Caron et al., 2006; Zagrarni et al., 2008; Navarro et al., 2009]. Jurassic filaments are thought to represent protoconchs or juvenile shells of posidoniid bivalves (Bositra, Posidonia), while Triassic occurrences are attributed to halobiid bivalves [Lapparent, 1923; Colom, 1955; Flügel, 2004]. Also pectinid bivalves of the Entolium group produce thin, filament-like shells, as documented for the Lias by Rivas et al. [1997]. For the Cretaceous filaments, no attribution to a genus has been proposed yet.

The present study describes filament accumulations within the Cenomanian-Turonian black shales constituting the Bahloul Formation [Burollet, 1956]. The Bahloul Formation and the Cenomanian-Turonian transition have been widely studied [Razgallah et al., 1994; Maamouri et al., 1994; Robaszynski et al., 1994; Accarie et al., 2000; Zagrarni, 1999; Abdallah et al., 2000; Hanini et al., 2004; Caron et al., 2006; Zagrarni et al., 2008], and provide the frame for the environmental interpretation of this "filament event". The purpose of this paper is to determine the origin of filaments and to reconstitute their deposition environment at local and global scales.

\section{GEOGRAPHIC AND GEOLOGIC SETTING}

Filaments were studied in the Late Cenomanian-Early Turonian black shales (up to $5 \%$ in Total Organic Carbon; [Layeb et al., 2001; Hanini et al., 2004]) of the Bahloul
Formation in western Central Tunisia (fig. 1). The surveyed sections are located, from the south to north, in the Gafsa area (Jebel Asker and Jebel Chemsi sections), the Kasserine area (Jebel Bireno section), the Kalaat Senan area (Oued Smara section), the Makthar area (Oued Bahloul and Ain Zaccar sections) and the Mateur area (Oued Bazina section).

During the Late Cenomanian - Early Turonian, platform facies was mainly expressed by shallow-marine carbonates (Gattar Formation) and occupied the central and southern part of Tunisia. Basinal facies, mainly represented by pelagic marls and argillaceous limestones, are found in the north, such as in the Oued Bazina area [Hanini et al., 2004; Zagrarni et al., 2008].

Transitional facies are mainly expressed by black shales containing pelagic foraminifera and ammonites, locally associated with conglomeratic carbonates and/or limestones that are rich in calcispheres and benthonic foraminifera (Bahloul Formation). These facies suggest an outer platform environment in the Makthar and Thala areas and are well represented in the Oued Bahloul section (fig. 1).

The maximum thickness of the Bahloul black shales is $100 \mathrm{~m}$ in the Kef area. In contrast, a condensed section is recognized in the southern Thala area (for example at Jebel Bireno) where the whole Bahloul Formation is less than $3 \mathrm{~m}$ thick. Emerged areas where the Bahloul facies is absent are located in the Kairouan area and locally in the gulf of Hammamet.

The Bahloul Formation spans three ammonite zones defined by Amédro et al. [2005]: from bottom to top, the upper part of Metoicoceras geslinianum, Pseudaspidoceras pseudonodosoides [Caron et al., 1999], and Watinoceras sp. [Caron et al., 1999; Zagrarni et al., 2008]. It also corresponds to the biozone defined by the pelagic foraminifer Whiteinella archaeocretacea [Ben Haj Ali et al., 1994; Maamouri et al., 1994; Caron et al., 1999]. The Bahloul 

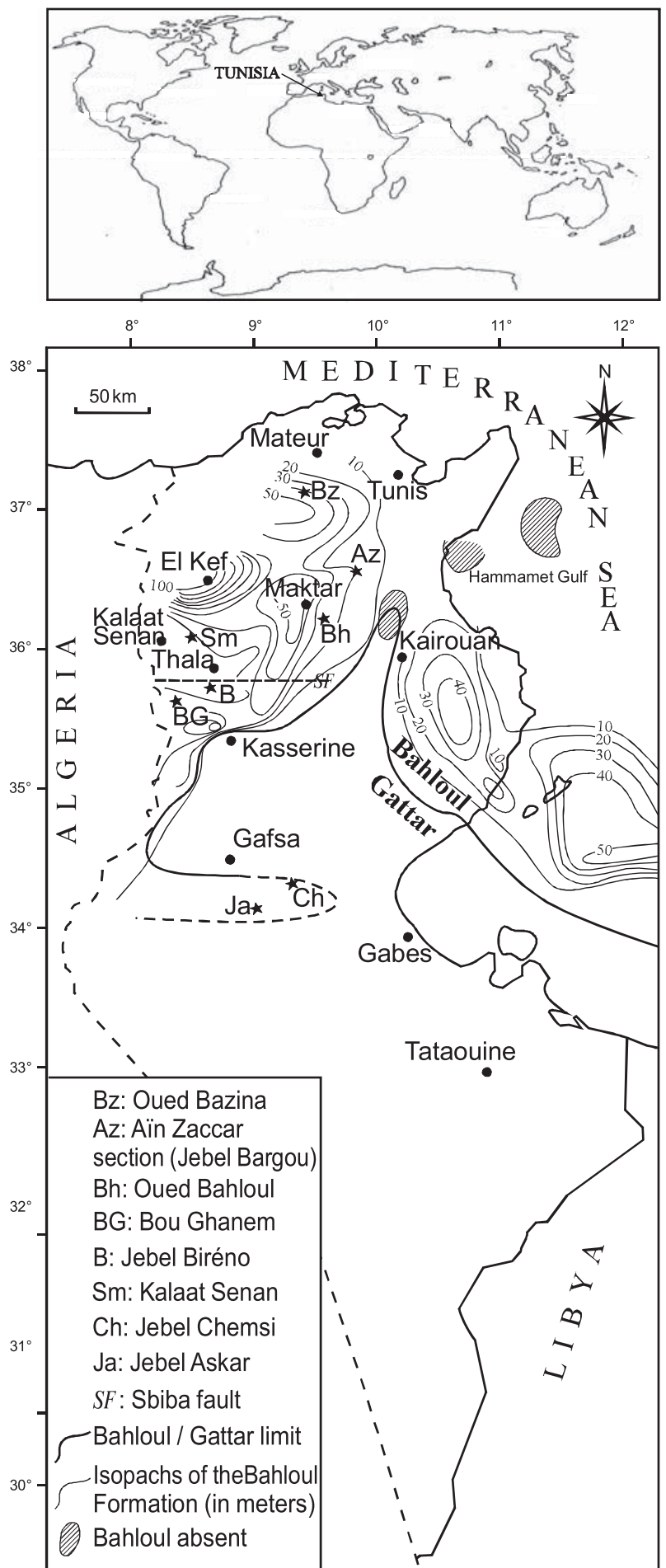

FIG. 1. - Location of the studied sections in Tunisia [Ben Ferjani et al., 1990, modified].

FIG. 1. - Localisation des coupes étudiées en Tunisie [Ben Ferjani et al., 1990, modifiée].

Formation overlies the Late Cenomanian marls of the Fahdene Formation, and is overlain by the marly Annaba Member (Kef Formation), Early Turonian in age (fig. 2).

\section{SEDIMENTARY CHARACTERISTICS OF THE BAHLOUL FORMATION}

\section{Vertical evolution of facies in the Oued Bahloul section}

The Bahloul Formation directly overlies a lensoid conglomeratic sandy limestone that incises the underlying marls of the Fahdene Formation. The sharp vertical change from marls to conglomeratic sandy carbonates and the irregular base of these conglomerates represent a clear discontinuity and are interpreted as a sequence boundary (fig. 2). The conglomeratic body exhibits well developed graded bedding and contains, preferentially within its lower part, centimetric lithoclasts and quartz grains, associated with bioclastic debris as well as benthonic and pelagic microfauna (essentially calcispheres and Rotalipora). This conglomeratic lens is well developed in the Oued Bahloul area and may correspond to a lowstand deposit (LST).

Vertically, the conglomeratic deposits abruptly change to well bedded laminated limestones (pl. I, fig. D) with marly layers (pl. I, fig. A). This lithologic change may correspond to a transgressive surface (TS) on which the Bahloul black shales were deposited. These black shales are organised into metric cycles [Caron et al., 1999; Hanini et al., 2004] composed of three lithologies (pl. I, fig. B). Each cycle starts with laminated dark grey limestone (pl. I, fig. C and D), progressively changes to argillaceous limestone, and terminates with bioturbated marls. Eleven such cycles are followed by a thick bed of dark grey limestone, which is overlain by a centimetric, strongly bioturbated limestone level, rich in ammonite molds and containing phosphate and glauconite grains. This thin bed coincides with the top of the Bahloul Formation (fig. 2). It is interpreted as a maximum flooding interval, with the maximum flooding surface at its top (MFS). Consequently, the Bahloul Formation can be attributed to the transgressive systems tract (TST) of a large-scale sequence. The overlying Annaba Member displays limestone-marl alternations, which correspond to highstand deposits (HST).

\section{Lateral facies changes}

Northeast of the Oued Bahloul section in Ain Zakkar (fig. 1), the Bahloul limestones contain, in addition to the planktonic foraminifera, calcispheres and filaments, also radiolarians [Srarfi, 1999], suggesting a relatively open marine environment.

More to the north, in the Bazina area, the Bahloul Formation is relatively thick (40 m) and is mainly composed of dark grey marls with common intercalations of laminated limestones (fig. 3) rich in planktonic foraminifera.

West of the Oued Bahloul section, at Kalaat Senan [Robaszynski et al., 1994], tempestites occur in the lower part of the Bahloul Formation. They are expressed by decimetric beds showing hummocky cross-stratification (pl. I, fig. F) and composed of packstones-grainstones rich in well-sorted calcispheres (pl. II, figs. E and F), planktonic foraminifera, and scarce filaments. The calcisphere-rich laminae are commonly seen interbedded with dark wackestones (pl. II, fig. A). The laminae are ondulating and locally have lensoid shapes (pl. II, figs. C and D). 


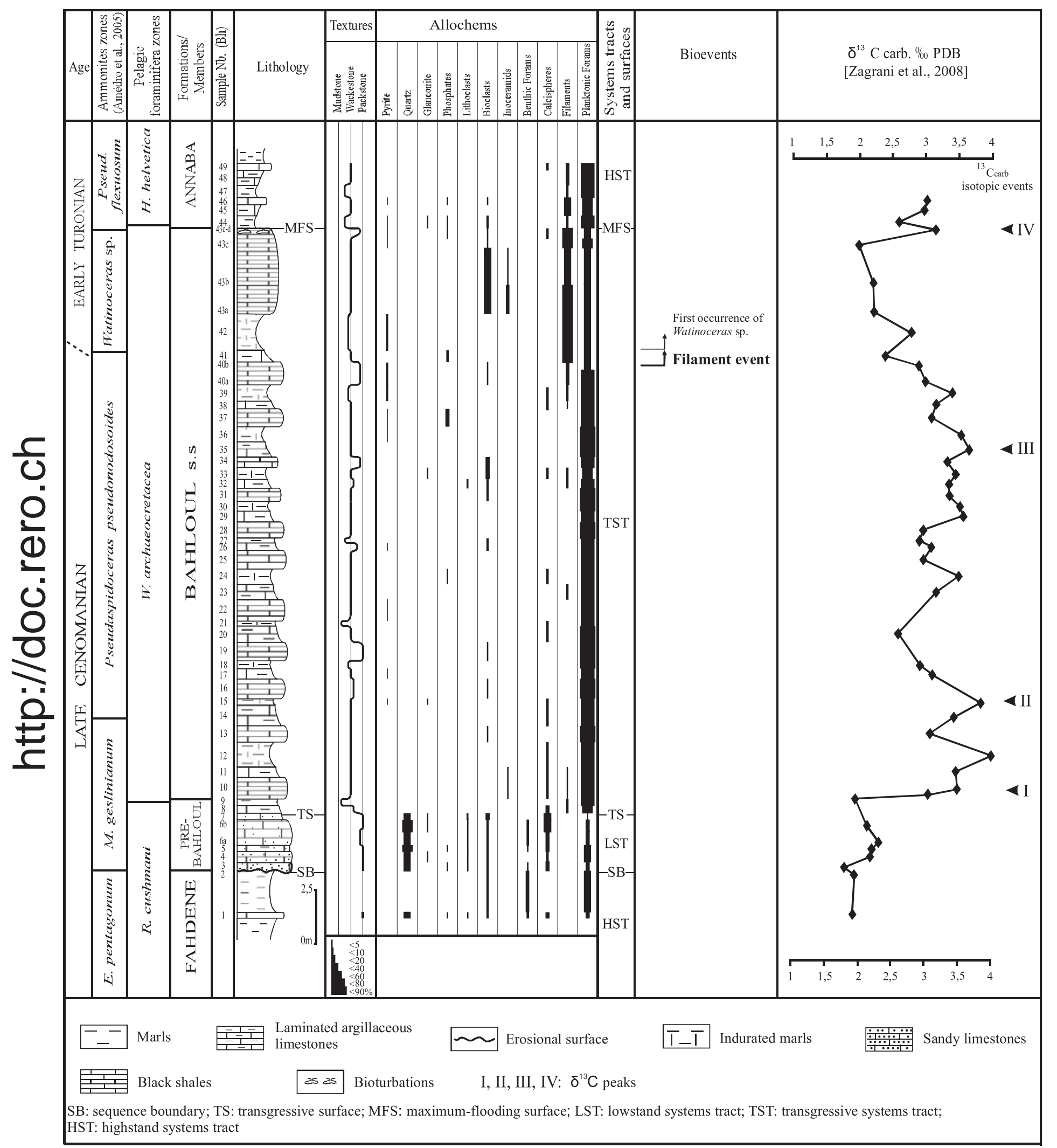

FIG. 2. - Stratigraphy, sedimentologic analyses and bulk carbon isotopes variations within the Bahloul Formation at Oued Bahloul [Zagrarni et al., 2008; modified]

FIG. 2. - Stratigraphie, analyse sédimentologique et variations de $\delta^{13} C_{\text {carb }}$ dans la Formation Bahloul [Zagrarni et al., 2008; modifiée] 
In the Kasserine area, at Jebel Bireno, the Bahloul Formation changes to carbonates represented by decimetric beds of laminated limestones with intercalations of argillaceous limestones (fig. 3). The laminated wackestones are rich in planktonic foraminifera and calcispheres. The lowermost part of the Bahloul exhibits hummocky cross-bedding (pl. I, fig. E), which implies storm influence. The top of the Bahloul Formation is marked by a condensed glauconitic and phosphatic bed.

More to the south in the Gafsa basin, especially at Jebel Chemsi and Jebel Asker, the equivalent of the Bahloul Formation has an erosive base and consists of $13 \mathrm{~m}$ of massively bedded limestones (fig. 3). They are locally dolomitised and have intercalations of laminated limestones [Razgallah et al., 1994; Abdallah et al., 2000]. These limestones are wackestones to packstones containing planktonic microfauna
(Heterohelicidae, Whiteinella sp., Hedbergella sp., and calcispheres), benthonic organisms (foraminifera, ostracodes, echinoids, gastropods, rudists, and other bivalves), and filaments.

In all studied sections, the top of the Bahloul Formation exhibits a centimetre-thick limestone bed that is strongly bioturbated, rich in ammonite molds, and contains phosphate and glauconite grains as well as filaments. This bed can be correlated regionally and is interpreted as a maximum-flooding deposit terminating the transgressive phase of the Bahloul Formation.

From north to south, the progressive lateral facies changes of the Bahloul Formation suggest a ramp environment. The abundance of planktonic foraminifera implies relatively deep-marine conditions. The lateral changes in thickness of the Bahloul Formation may be due to
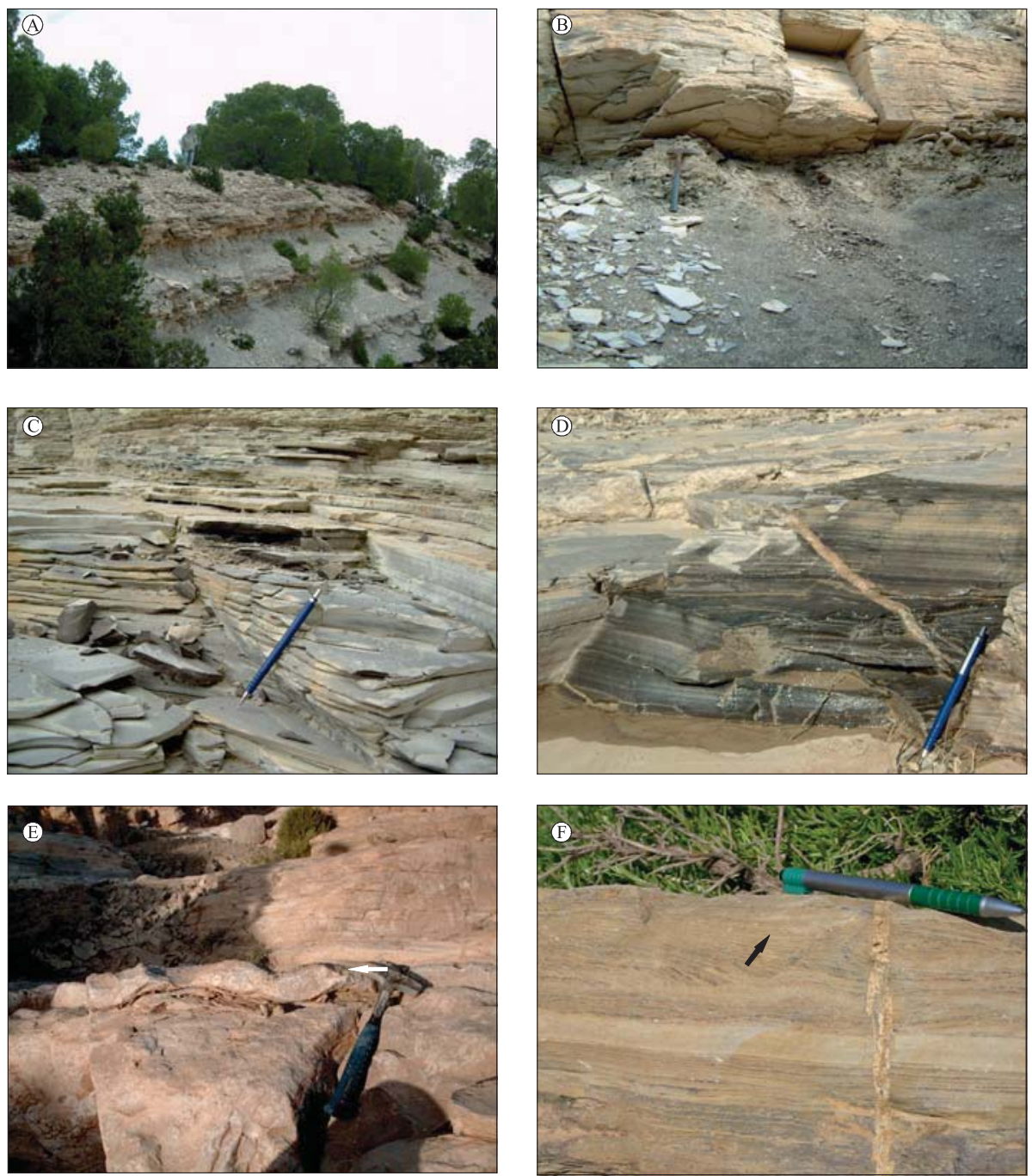

PLATE I. - (A) Laminated limestone-marl alternations of the Bahloul Formation (Oued Bahloul section). (B) Deepening upward cycle starting by laminated black shales progressively changing to marls (Oued Bahloul section). (C) The Bahloul Formation black shales (Oued Bahloul section). (D) Laminated limestones of the Bahloul Formation, showing alternation of dark laminations and lighter facies (Oued Bahloul section). (E) Hummocky cross beddings (arrow) fossilised at the lowermost part of the Bahloul laminated limestones (Jebel Bireno section). (F) Decimetric tempestitic bed showing hummocky cross beddings (arrow) intercalated within the lower part of the Bahloul Formation (Kalaat Senan section).

PL. I. - (A) Calcaire laminé et intercalations marneuses de la formation Bahloul (coupe de l'Oued Bahloul). (B) Cycle transgressif débutant par des calcaires noirs laminés qui passent progressivement à des marnes (coupe de l'Oued Bahloul). (C) Calcaires laminés en plaquettes de la formation Bahloul (coupe de l'Oued Bahloul). (D) Calcaires laminés montrant l'alternance de lamines noires et de lamines claires (coupe de l'Oued Bahloul). (E) Stratifications en mamelons (flèche) dans la partie basale de la formation Bahloul (coupe du Jebel Biréno). (F) Stratifications en mamelons (flèche) dans la partie inférieure de la formation Bahloul (coupe de Kalaat Senan) 
differential subsidence and localised condensation [Zagrarni et al., 2008]. The organic-rich facies of the laminated dark limestones points to periodic eutrophication of the surface waters and to anoxic conditions on the sea bottom [Caron et al., 1999; Van Buchem et al., 2002], while the bioturbated marls suggest an oxygenated sea floor. This has been explained by orbitally driven changes from a more arid to a more humid climate [Caron et al., 1999]. During the arid phase, run-off of hypersaline waters from a shallow platform would have produced stratification of the water column and anoxic bottom waters on the ramp, whereas during humid conditions, this saline barrier was absent and the waters were well mixed. At a global scale, the Bahloul black shales express a crisis, which was identified during this period, in several oceans. This crisis is correlatable to the oceanic anoxic event 2 (OAE 2 [e.g. Van Buchem et al., 2002; Jarvis et al., 2006; Zagrarni et al., 2008]).

\section{THE FILAMENT EVENT}

\section{The filament event in Tunisia}

In Tunisia, the filament event is expressed by the abundance of filaments occurring mainly in the black shales of the upper part of the Bahloul Formation (pl. III, figs. A, B) and continuing into the argillaceous limestones of the lower part of the Annaba Member. Foraminifera biostratigraphy indicates that the filaments span to the upper part of the Whiteinella archaeocretacea biozone (Late Cenomanian to Early Turonian) to the lower part of Helvetoglobotruncana helvetica biozone, (Early Turonian; fig. 2). The filament event is recorded in several sections (fig. 3) such as in Oued Bahloul [Maamouri et al., 1994; Caron et al., 2006;
Zagrarni et al., 2008], in Jebel Biréno [Zagrarni, 1999; Zagrarni et al., 2008], in the Ouled Bou Ghanem area, in the Kalaat Senan area [Robaszynski et al., 1994; Amédro et al., 2005], in the Ain Zakkar section [Srarfi, 1999], in the Kef area [Nederbragt and Fiorentino, 1999] and in the Gafsa basin [Razgallah et al., 1994; Abdallah et al., 2000].

The filament event, which is characterised by an interval with abundant filaments that can constitute up to $40 \%$ of all allochems, was useful for regional and global correlations. They occur as individual shells or are packed into bundles. Entire bivalve shells (pl. III, fig. C) are $4.5 \mathrm{~mm}$ in average length and $0.3 \mathrm{~mm}$ in average thickness. Most shells, however, are disintegrated into pieces, which are $0.8 \mathrm{~mm}$ in average length and $0.01 \mathrm{~mm}$ in average thickness (pl. III, fig. A; pl. IV, fig. C). Besides fragmentation, the shells do not exhibit any taphonomic features such as borings or encrustations. Entire and fragmented shells commonly show a preferential orientation parallel to bedding. Locally, filament-rich layers include lens-shaped laminae rich in planktonic foraminifera (pl. II, fig. B).

\section{The filament event in the world}

Outside of Tunisia, the filament event has been described in several areas (fig. 4) such as in Algeria [Naili et al., 1995], Morocco [Ettachfini et al., 2004], USA (Pueblo section, Colorado; D'All Agnolo [2001]), South Tibet [Wan et al., 2003] and Oman [Van Buchem et al., 2002]. In these sections, the filament event occurs in the same stratigraphic interval as in Tunisia, i.e. at the Cenomanian-Turonian boundary, corresponding to the upper part of the Whiteinella archaeocretacea biozone and the lower part of the Helvetoglobotruncana helvetica biozone (fig. 4).

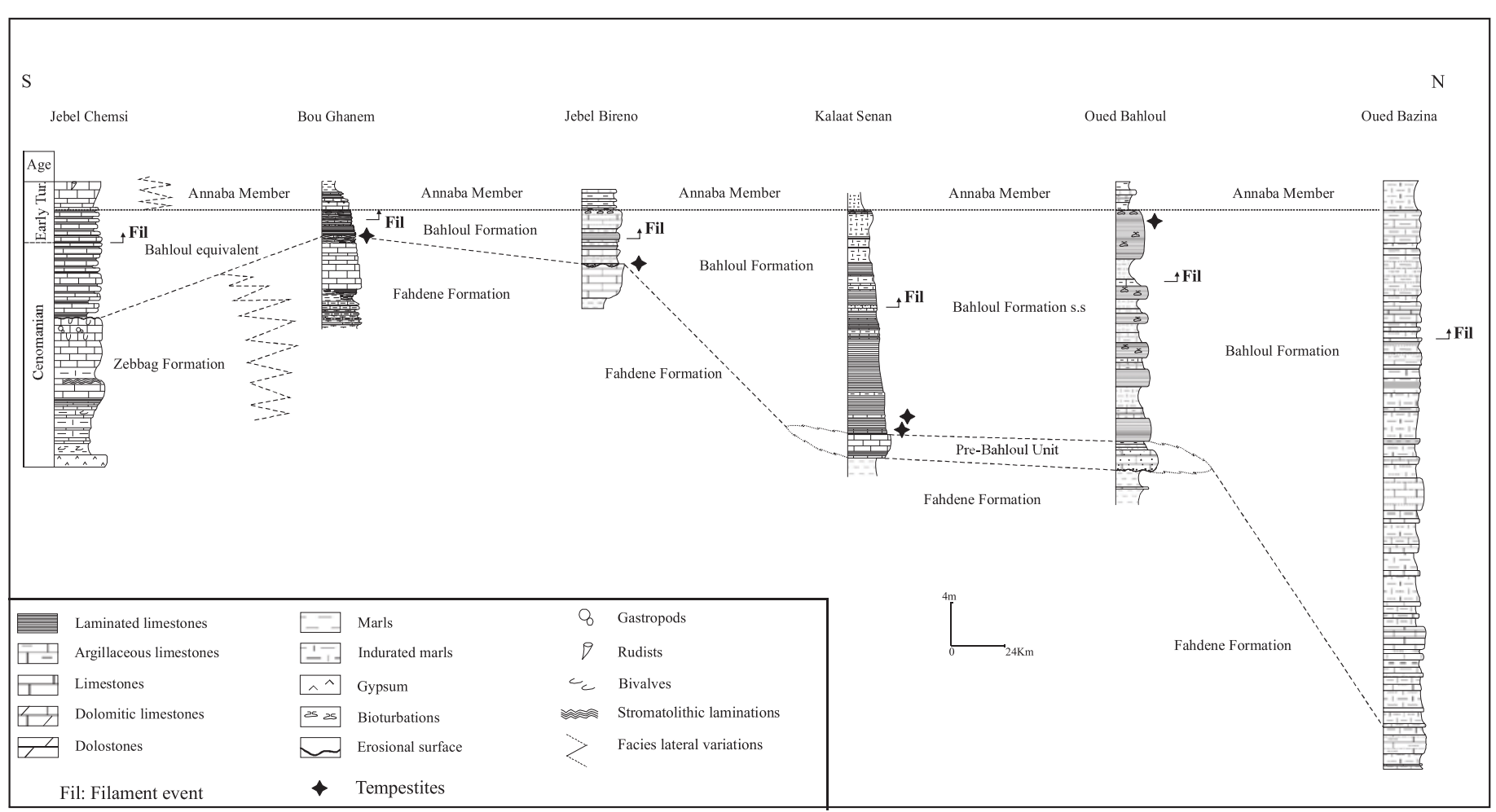

FIG. 3. - Biolithostratigraphic correlation and location of the filament event in the Bahloul Formation (Tunisia).

FIG. 3. - Corrélation biolithostratigraphique et position du "filament event" dans la formation Bahloul en Tunisie. 

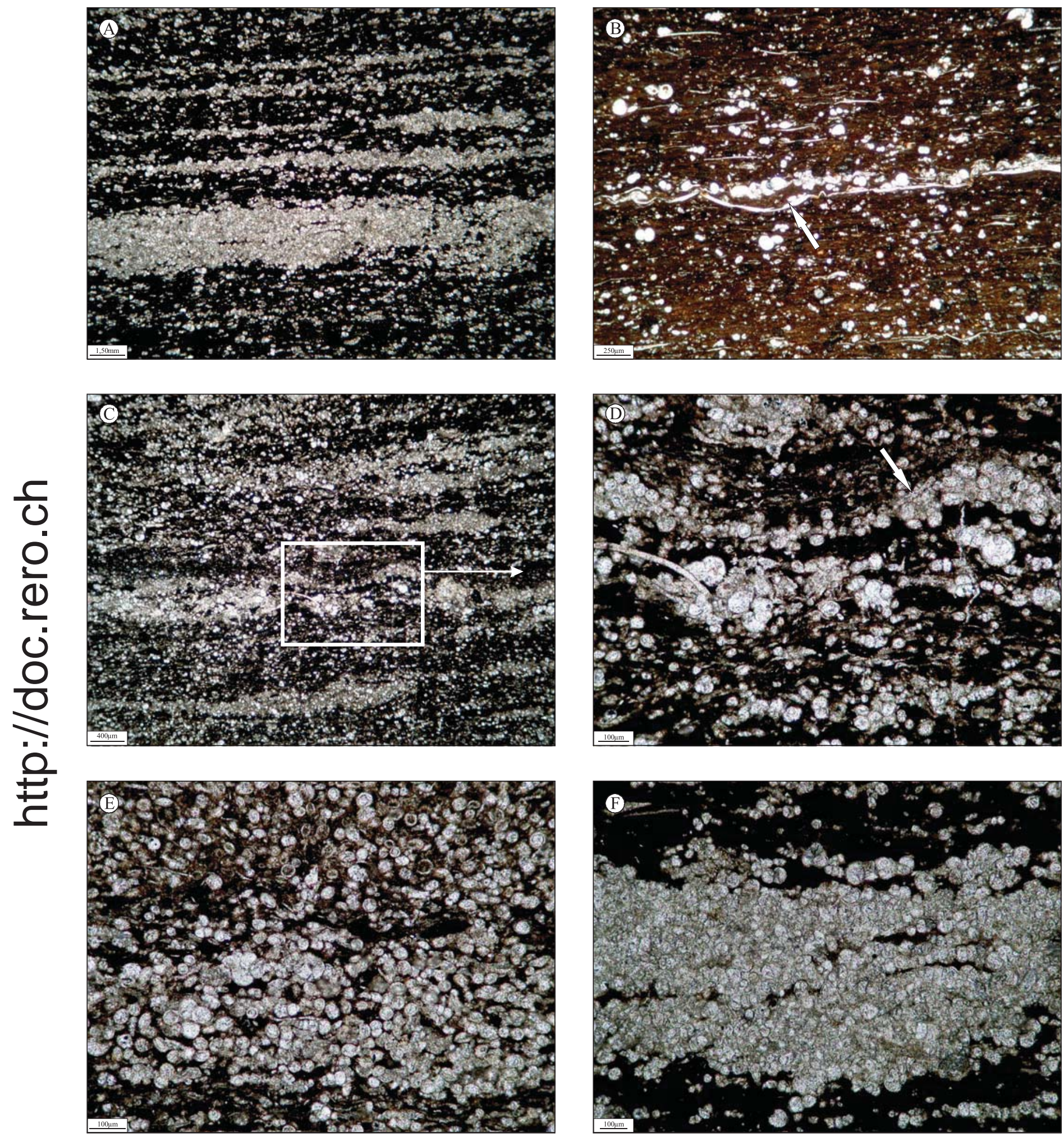

PLATE II. - (A) Micrograph showing tempestites expressed by alternations of dark micritic-rich wackestones and lighter calcispheres-rich packstones to grainstones (Kalaat senan section). (B) Wackestone containing planktonic foraminifers associated to filaments and admitting the intercalation of microbeds (arrow) rich in loosely packed planktonic foraminifers illustrating resedimentation processes during storms (Oued Bahloul section). (C) Calcisphere-rich microbeds organised into undulated laminations showing a lensoid shape (Kalaat senan section). (D) Detailed view showing undulated laminations (arrow) formed of loosely packed calcispheres associated to scarce filaments. (E, F) Tempestitic microfacies formed of packstones rich in well sorted and compacted calcispheres (Kalaat senan section).

PL. II. - (A) Microfaciès montrant des tempestites exprimées par des alternances de wackestones sombres et de packstones-grainstones clairs, riches en calcisphères (coupe de Kalaat Senan). (B) Wackestone à foraminifères plactoniques et filaments, admettant une intercalation de microlits de texture packstone-grainstone (flèche) exprimant une resédimentation accompagnant une phase tempestitique (coupe de l'Oued Bahloul). (C) Microlits riches en calcisphères, organisés en laminations ondulées et montrant des formes lenticulaires (coupe de Kalaat Senan). (D) Vue détaillée de la photo C, montrant des laminations ondulées (flèche) composées de packstones-grainstones à calcisphères et rares filaments. (E, F) Microfaciès de dépôts de tempêtes, formés par des packstones à calcisphères bien triés et compactés (coupe de Kalaat Senan). 


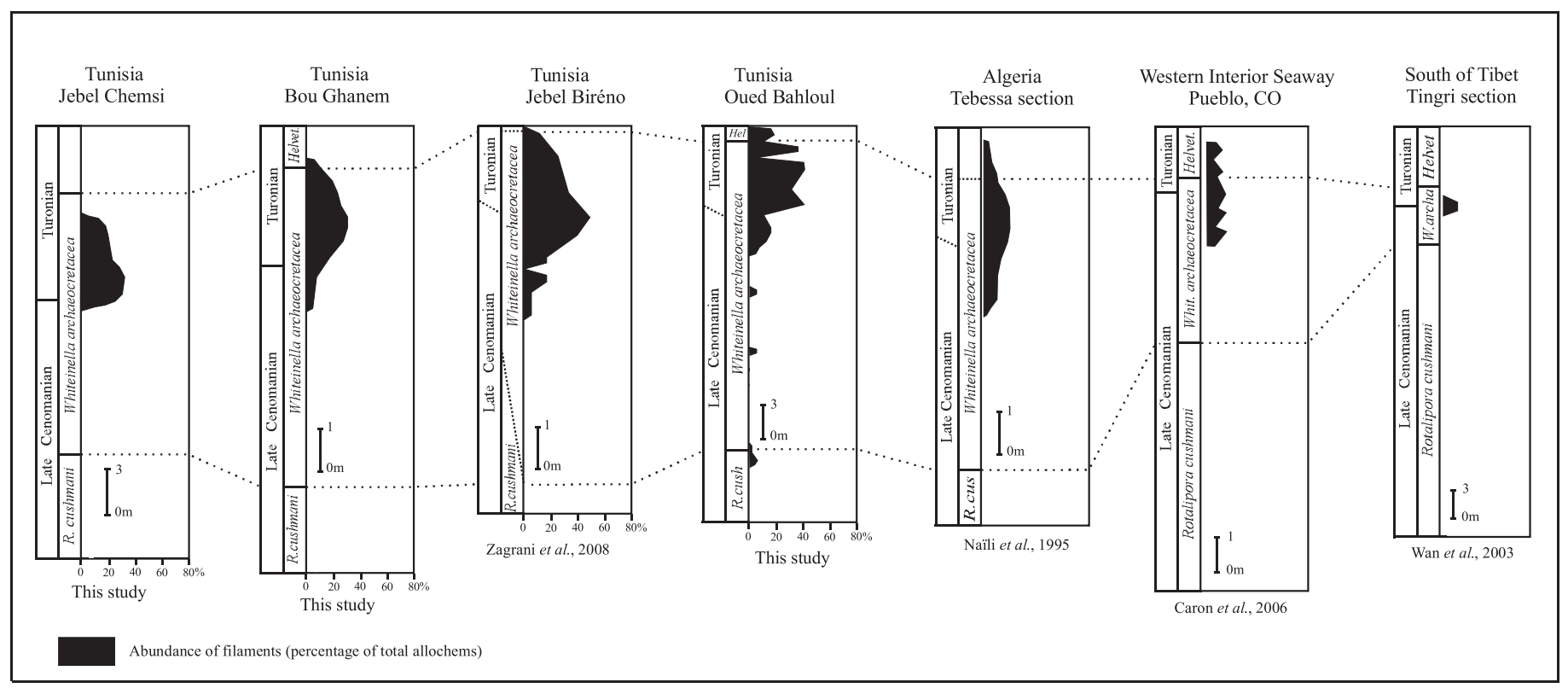

FIG. 4. - Global correlation of the Cenomanian-Turonian interval, based on the filament event.

FIG. 4. - Corrélation globale de l'intervalle Cénomanien-Turonien, basée sur le "filament event".

Other events (fig. 5) such as the positive $\delta^{13} \mathrm{C}$ excursion [Jarvis et al., 2006] and the first occurrence of Turonian ammonites, especially the genus Watinoceras [Zagrarni, 1999; Amédro et al., 2005; Caron et al., 2006], were also identified near the Cenomanian-Turonian boundary. These events appear to be related to a eustatic sea-level rise. In Tunisia, the filament-rich layers are found in the upper part of the transgressive deposits of the Bahloul Formation and around the maximum flooding surface at the lower limit to the Annaba Formation (see above). Furthermore, this maximum flooding surface also coincides with a positive $\delta^{13} \mathrm{C}$ excursion (peak IV; fig. 2) immediately coming after a negative $\delta^{13} \mathrm{C}$ excursion, which starts just at the beginning of the filament event. It means that the filament event is situated within a negative $\delta^{13} \mathrm{C}$ excursion. Consequently, the filament event can be correlated at a regional and global scale, suggesting that it reflects a global event. Furthermore, it appears to be related to a context of late transgression and maximum flooding.

\section{FILAMENT ORIGIN}

\section{Petrographic data}

Detailed petrographic studies of filament beds have been conducted in three Tunisian sections: in the Bazina section located in a basinal setting, in Oued Bahloul, located in an outer ramp setting, and in Jebel Bireno, occupying an inner ramp position. Filament shapes, dimensions and orientations are different in the three sections.

In the Bazina section, marls and argillaceous limestones constituting the upper part of Bahloul Formation are rich in entirely to partly fragmented pelagic bivalve shells.

In Oued Bahloul, filaments occur in laminated black shales alternating with laminated limestones. The latter show alternations of dark grey and light grey millimetric laminae. Dark laminae are rich in organic matter (up to $5 \%$ in Total Organic Carbon) and contain scarce and badly preserved pelagic microfauna (calcispheres, foraminifera). However, light grey laminae contain loosely packed filaments and well preserved globular planktonic foraminifera and calcispheres (pl. IV, fig. B). In some grey laminae, the filaments are densely packed (pl. III, figs. C, D and E; pl. IV, fig. A).

Some filaments are longer (up to $800 \mu \mathrm{m}$ long) and preferentially oriented parallel to stratification (pl. IV, figs. B and C). Locally, long filaments show undulated forms where they are loosely packed with globular planktonic foraminifera. This implies a compaction process, whereby filaments are wrapped around more rigid bioclasts and follow the shape of foraminifera chambers (pl. III, fig. F). Also the tepee-like structure shown in plate III, figures $\mathrm{D}$ and $\mathrm{E}$, is interpreted as having formed through compaction, with a crinoid-fragment serving as rigid obstacle above which the filaments have been upturned. Similar compaction-related features have been illustrated by Navarro et al. [2009] in filament lumachelles from the Middle Jurassic of Spain.

In Jebel Bireno, representing a platform setting, filaments occur in massively bedded limestones, which consist of wackestones-packstones containing planktonic foraminifera and scarce calcispheres. The filaments are smaller $(200 \mu \mathrm{m}$ in average length), isolated, and show varied orientations (pl. III, fig. B; pl. IV, D).

\section{Linkage between filament shape and depositional environment}

The petrographic analyses show that the shape, length, and orientation of the filaments are linked to the depositional environment.

Wackestones containing well preserved pelagic bivalves (pl. III, fig. C) reflect a low-energy depositional environment, 
below fair-weather wave base. While settling of shells on the sea floor would have led to an orientation parallel to bedding, bioturbation could reorient the shells into a chaotic texture (pl. IV, fig. D). On the other hand, the laminae with densely packed filaments as well as the graded bedding of the laminae rich in planktonic foraminifera (pl. II, fig. B) suggest episodic higher-energy events generated by bottom currents. Considering that hummocky cross-stratification is observed in the lower part of the Bahloul Formation and that there is a general deepening-up trend towards the filament event, the laminae rich in filaments and/or planktonic foraminifera can be interpreted as distal tempestites. During storms, most bivalve shells were remobilised and broken into fragments. Probably, the more the fragments are broken and small, the longer the transport distance from source to final deposition was. However, care has to be taken with this interpretation because also compaction causes breaking of the thin bivalve shells [Rivas et al., 1997]. Deposition and burial must have been rapid because the shells do not show any micritisation, bioperforation, or encrustation. In the Middle Jurassic of Spain, Molina et al. [1997] and Navarro et al. [2009] describe tempestites rich in filaments, which, however, are more proximal and exhibit
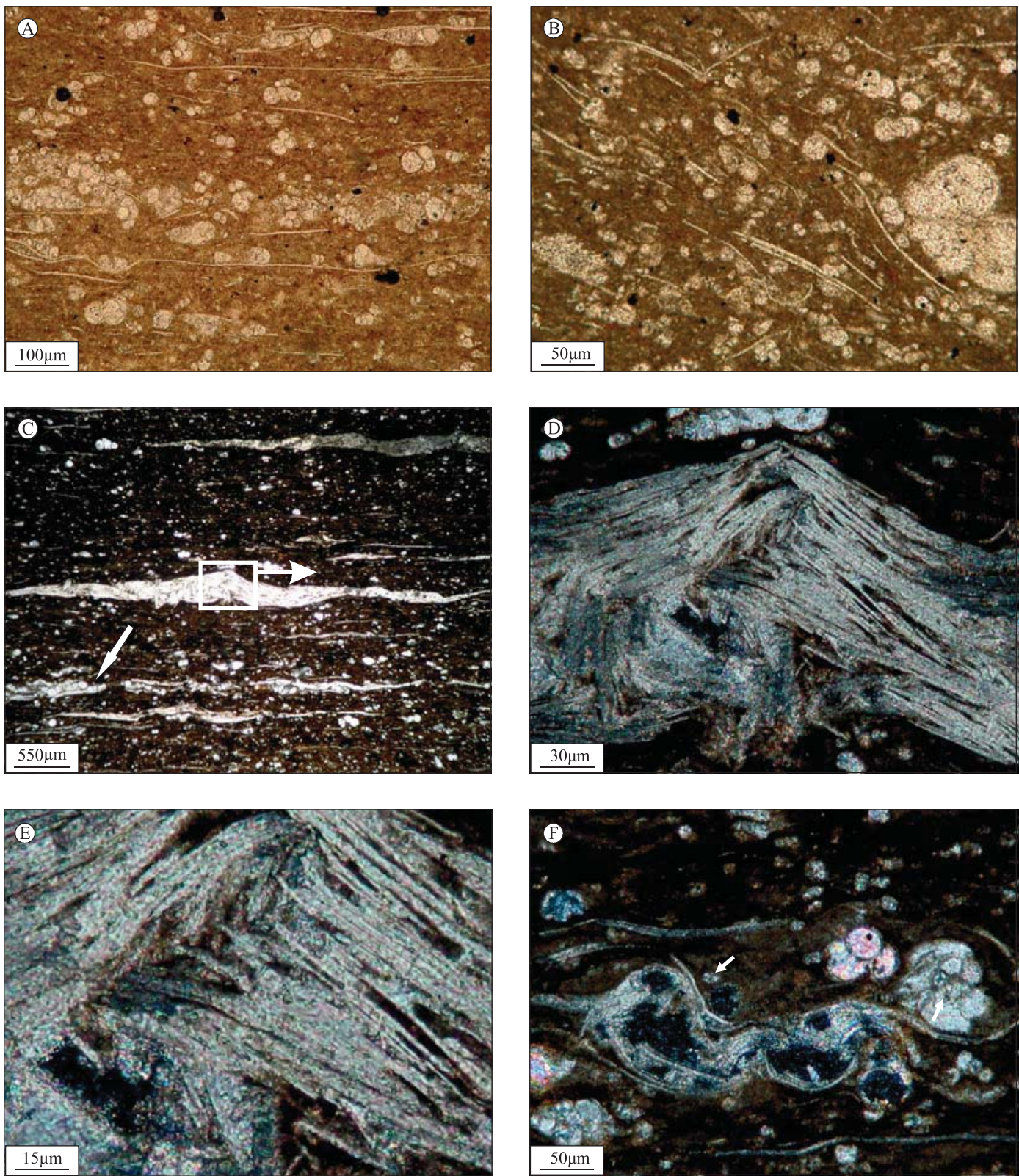

PLATE III. - (A) Wackestone rich in oriented filaments associated with planktonic foraminifers (Oued Bahloul section). (B) Wackestone rich in planktonic foraminifers and containing multidirectional filaments (Jebel Bireno section). (C) Wackestone containing entire bivalve shells and filamented bundles, showing a preferred orientation parallel to bedding (Oued Bahloul section). (D-E) Detailed views showing the filamented structure characterising the identified pelagic bivalves (Oued Bahloul section). (F) Undulated filaments taking the form of forminifera chambers (arrows) in Oued Bahloul section. PL. III. - (A) Wackestone à filaments orientés et foraminifères planctoniques (coupe de l'oued Bahloul). (B) Wackestone à filaments désorientés et foraminifères planctoniques (coupe du Jebel Biréno). (C) Wackestone à coquilles de bivalves pélagiques montrant des baguettes calcitiques orientés parallèlement à la stratification (coupe de l'oued Bahloul). (D, E) Vues détaillées montrant la microstructure filamenteuse des bivalves pélagiques (coupe de l'oued Bahloul). (F) Filaments ondulées (flèche) épousant la forme des loges des foraminifères planctoniques (coupe de l'oued Bahloul). 

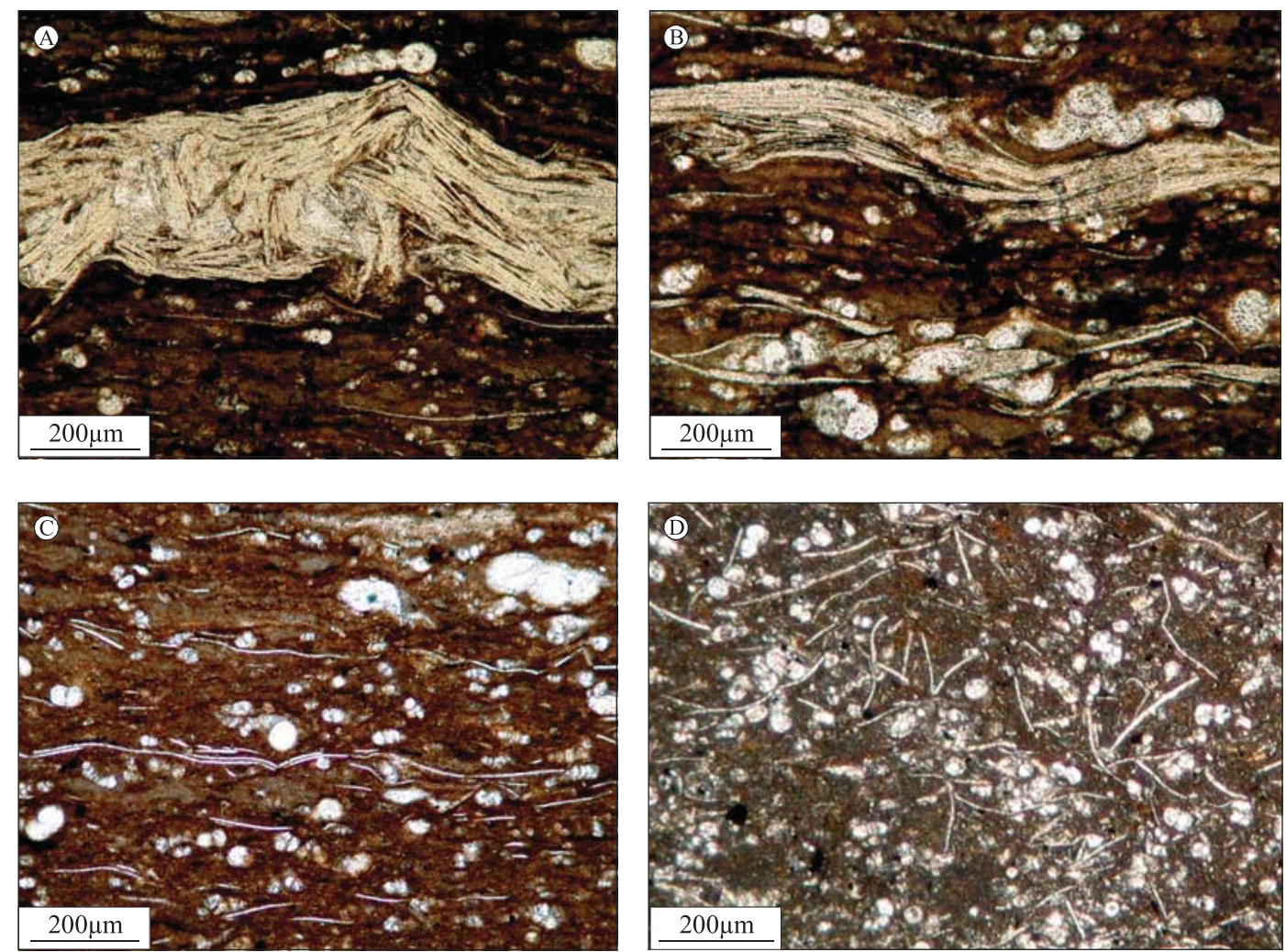

PLATE IV. - The different steps of filaments genesis and their relationship to deposition environments. (A) Well preserved pelagic bivalve shell in outer shelf to "basinal" environments (Oued Bahloul section). (B) Partial disintegration of bivalve shells into filamented packed structures in a distal outer ramp environment (Oued Bahloul section). (C) Genesis of elongated and arcuate filaments in a proximal outer ramp environment (Oued Bahloul section). (D) Multidirectional "small" and thin filaments in a platform environment (Jebel Biréno section).

PL. IV. - Les différentes étapes dans la genèse des filaments et ses relations avec les milieux de dépôt. (A) Coquilles bien préservées de bivalves pélagiques, identifiées à la limite plate-forme - bassin (coupe de l'oued Bahloul). (B) Désintégration partielle des coquilles en fragments à structures filamenteuses dans la partie distale de la rampe externe (coupe de l'oued Bahloul). (C) Genèse de filaments allongés et arqués dans la partie proximale de la rampe externe (coupe de l'oued Bahloul). (D) Filaments courts, fins et désorientés dans un milieu de rampe (coupe du Jebel Biréno).

hummocky cross-stratification. In the Early Jurassic of Spain, Rivas et al. [1997] interpret the layers of Entolium shells as distal tempestites in a starved pelagic setting.

The proliferation of pelagic bivalves in a ramp environment could be related to up-welling and/or run-off from the continent, which provided nutrients. This postulated abundance of nutrients is consistent with the organic-rich facies included within the Bahloul Formation, where the organic matter was preserved in an oxygen-minimum zone [Caron et al., 1999]. It is also consistent with the low abundance of benthic organisms in the Bahloul Formation. In Spain, Rivas et al. [1997] mention dysaerobic conditions where small Entolium shells accumulated but otherwise not much benthos could live.

For the cited examples in the Jurassic of Spain there is evidence that the filaments accumulated during a transgressive phase of sea-level evolution. Rivas et al. [1997] consider them as "a peculiar type of hiatal shell concentrations associated with transgressive or highstand regimes". Navarro et al. [2009] explain the abundance of opportunistic species such as Bositra and Entolium as a sign of carbonate productivity crisis related to the drowning of a shallow carbonate platform.

In the case of the filament event in Tunisia, the transgressive context suggested by the sequence-stratigraphic interpretation of the Bahloul Formation. Transgression also led to a low-oxygen environment on the sea floor.

\section{DISCUSSIONS}

In addition to the filament event, other bio-events [Caron et al., 2006; Zagrarni et al., 2008] were used to establish correlations in North Africa and in other continents (fig. 5). These bio-events are especially the extinction of the genus Rotalipora, the first occurrences of $W$. archaeocretacea, Watinoceras and H. Helvetica. The extinction of Rotalipora is explained by a loss of water column density gradients at the end of the Cenomanian [Leckie et al., 2002].

These bio-events are the expression of communications between different oceans such as the Tethys, the Proto-North Atlantic, the Western Interior Seaway and the Norwegian Seaway [Zagrarni et al., 2008] during the late Cenomanian-early Turonian interval.

In terms of sequence stratigraphy, some of these bio-events correspond to sequence surfaces: the extinction of Rotalipora and the first occurrence of $W$. archaeocretacea coincide with a transgressive surface, which constitutes the base of the Bahloul black shales.

In terms of ages of the Cenomanian-Turonian boundary, the limit between the planktonic foraminifer zones Archaeocretacea and Helvetica (fig. 2), corresponding to 


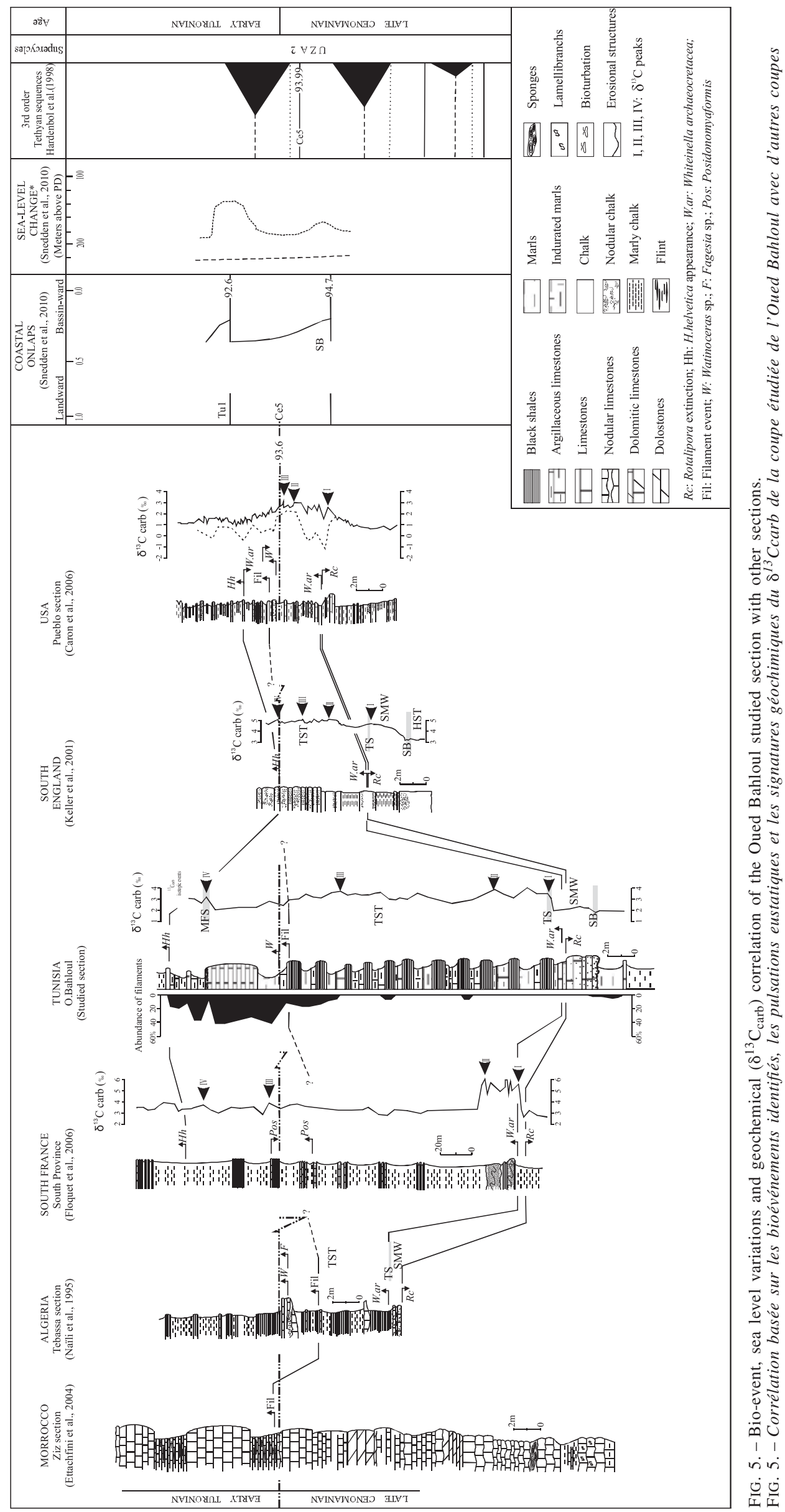


the maximum-flooding surface at Oued Bahloul, is dated at 93.3 Ma. According to Leckie et al. [2002], the OAE2 at the Cenomanian-Turonian boundary is near 93.5 Ma.

In terms of chronostratigraphy, the filament event has a relative great importance since it provides a chronostratigraphic value. In fact, the accumulation of filaments is registered in great number just before or near the first Turonian marker ammonite corresponding to Watinoceras genus. When the Watinoceras Turonian marker is rare or absent, the first layer in which filaments are abundant could be used as a very good proxy to the Cenomanian-Turonian boundary.

In Oued Bahloul section, the Sequence boundary (SB) at the base of the Pre-Bahloul unit [Accarie et al., 2000] is in a stratigraphic position similar to SB Ce5 in other European basins [Zagrarni et al., 2008], which is dated at 93.99 Ma [Hardenbol et al., 1998]. The age of the overlying maximum-flooding surface, about $93.3 \mathrm{Ma}$, is in agreement with other studies.

The good regional and global correlation of this filament event points to a eustatic sea-level rise, which is also documented in the sequence-chronostratigraphic chart of Hardenbol et al. [1998] compiled for European basins: an important maximum flooding occurred 93.1 Ma ago in the Coloradoense/Devonense ammonite zone. The sea-level rise is related to a global scale (i.e, first-order) sea-level change since the mid-Cretaceous was a time of transition in the nature of the ocean-climate system [Leckie et al., 2002]. In fact, increased ocean crust production coupled to tectonic and volcanic activities contributed to a greenhouse world of clearly rising sea-level and warming global climate that peaked in the lowermost early Turonian [Leckie et al., 2002].

In the Arabian platform, the Cycle Chart [Haq and Al-Qahtani, 2005] shows that the Turonian major maximum-flooding surface (base of the transgressive-regressive K140 cycle) occurred at $93 \mathrm{Ma}$ [in Sharland et al., 2004] and also at $93 \mathrm{Ma}$ after an age recalibration to GTS 2004 in Gradstein [2004]. The Cenomanian-Turonian boundary is located at $93.5 \mathrm{Ma}$.

After age recalibrations for the Mesozoic-Cenozoic interval to the 2004/2008 timescale [Snedden and Liu, 2010], the age of the Turonian maximum-flooding surface (93 Ma) is still comparable to that attributed by Hardenbol et al. [1998] in the $3^{\text {rd }}$ order Tethyan sequences. According to this study, the Cenomanian-Turonian boundary is located at 93.6 Ma.

On the whole, the maximum-flooding surface, on top of the Bahloul black shales, has an age near 93.3 Ma, which is in agreement with that defined in other studies [Hardenbol et al., 1998; Gradstein, 2004; Haq and Al-Qahtani, 2005; Snedden and Liu, 2010]. The discrepancy of 300000 years may be related to problems of dating and/or to different expressions of the maximum-flooding in different basins.

On the other hand, in addition to a global scale (i.e., first-order) sea-level change (discussed before), higher frequency (third-order) sea level changes appear also to controll the expression of the filament event in the Bahloul black shales. As compared with other basins, the filament event occurs during very high sea level conditions (highest amplitudes in Meso-Cenozoic times), immediately below the Cenomanian-Turonian boundary [93.6 Ma; Snedden and
Liu, 2010], near the maximum-flooding surface [at about $93 \mathrm{Ma}$; Snedden and Liu, 2010].

These very high sea level conditions seem favourable to oceanic anoxia in some restricted areas and, then, to the accumulation of organic-rich clays such as the Bahloul black shales.

From a paleoecological point of view, the abundance of filaments near the Cenomanian-Turonian boundary could also express a heightened marine productivity, which is related to widespread changes in the oceanic-climate system. These changes mainly concern ocean circulation, water column stratification and nutrient partitioning [Leckie et al., 2002].

\section{CONCLUSIONS}

The filament event, which was described in Tunisia and in other countries, corresponds to the occurrence of filaments generated from the disintegration of pelagic bivalve shells that accumulated in black shales in ramp environment. This event occurred near the Cenomanian-Turonian boundary and is associated with other events such as a $\delta^{13} \mathrm{C}$ excursion and the first occurrence of Turonian ammonites, especially the Watinoceras genus. It also coincides with the boundary between the Archaeocretacea and Helvetica foraminifer biozones.

Petrographic studies show a clear relationship between filaments and the depositional environment. Preserved pelagic bivalve shells are identified in outer ramp to basinal environments. The disintegration of the shells into assemblages of packed filaments and into isolated, smaller filaments appears to have been under the control of episodic high-energy conditions, probably generated by storms. In some samples, the filaments constitute up to $40 \%$ of the allochems. They are commonly arranged parallel to bedding but may be oriented chaotically due to bioturbation or differential compaction around other bioclasts.

The filament event occurred towards the end of a globally recognized eustatic sea-level rise, which induced bottom anoxia and led to the deposition of the Bahloul black shales. The condensation level at the top of the Bahloul Formation corresponds to the maximum flooding recognized in many basins in the world. The age of 93.3 Ma, attributed to this maximum-flooding surface, is comparable to that determined in other basins [Hardenbol et al., 1998; Gradstein, 2004; Haq and Al-Qahtani, 2005; Snedden and Liu, 2010]. This maximum-flooding surface which announces the end of the filament event/black shales postdates the Cenomanian-Turonian boundary [93.5 to 93.6 Ma, respectively according Haq and Al-Qahtani, 2005 and Snedden and Liu, 2010].

On the other hand, the filament event could be used as a chronostratigraphical marker when the Watinoceras genus is rare or absent. Filament-rich facies are indicators for the Cenomanian-Turonian boundary proximity.

Concerning the paleoecological aspect, the filament event could be also an expression of the heightened marine productivity, which is due to widespread changes in ocean circulation, water column stratification and nutrient partitioning. 


\section{References}

Abdallah H., Sassi S., Meister C. \& Souissi R. (2000). - Stratigraphie séquentielle et paléogéographie à la limite Cénomanien-Turonien dans la région de Gafsa-Chotts (Tunisie centrale). - Cret. Res., 21, 35-106.

Accarie H., Robazynski F., Caron M. \& Zagrarni M.F. (2000). - Stratigraphie événementielle au passage Cénomanien-Turonien dans le secteur occidental de la plate-forme de la Tunisie centrale (formation Bahloul, région de Kalaat Senan). - Annales des $\mathrm{Mi}$ nes et de la Géologie, Tunisie, 40, 63-80.

Amédro F., AcCARIE H. \& Robaszynski F. (2005). - Position de la limite Cénomanien-Turonien dans la formation Bahloul de Tunisie centrale: apports intégrés des ammonites et des isotopes du carbone $\left(\delta{ }^{13} \mathrm{C}\right) .-$ Eclogae geol. Helv., 98, 151-167.

Ben Ferjani A., Burollet P. F. \& Mejri F. (1990). - Petroleum geology in Tunisia. - E.T.A.P. 1, 121-125.

Ben Haj Ali N., Razgallah S., Ben Haj Ali M. \& Kennedy J.W. (1994). - La formation Bahloul dans sa localité type: précisions stratigraphiques basées sur les ammonites et les foraminifères planctoniques. - Notes Serv. Géol. Tunisie, 60, 35-58.

Burollet P.F. (1956). - Contribution à l'étude stratigraphique de la Tunisie centrale. - Annales des Mines et de la Géologie, Tunisie, 18, $1-345$.

Caron M., Robaszynski F., Amédro F., Baudin F., Deconinck J.-F., Hochli P., Von Salis-Perch Nielsen K. \& Tribovillard N. (1999). Estimation de la durée de l'événement anoxique global au passage Cénomanien-Turonien. Approche cyclostratigraphique dans la formation Bahloul en Tunisie centrale. - Bull. Soc. géol. Fr. 170, $145-160$.

Caron M., Dall'Agnolo S., Accarie H., Barrera E., Kauffman E.G., AMEdRo F. \& RobAsZYnski F. (2006). - High-resolution stratigraphy of the Cenomanian-Turonian boundary interval at Pueblo (USA) and wadi Bahloul (Tunisia): stable isotope and bio-events correlation. - Geobios, 39, 171-200.

Colom G. (1955). - Jurassic-Cretaceous pelagic sediments of the western Mediterranean zone and the Atlantic area. - Micropaleontology, 1, 109-124.

D'All Agnolo S. (2001). - Written communication (22-03-2001) in University of Fribourg, Suisse (cours bloc BENERFI).

EtTAChFini E.M. \& Andreu B. (2004). - Le Cénomanien et le Turonien de la plate-forme Préafricaine du Maroc. - Cret. Res., 25, 277-302.

Floquet M., Philip J., Leonide P. \& Gari J. (2006). - Sédimentation et géodynamique du Bassin sud-provençal au Crétacé supérieur. Livret-guide d'excursion géologique. - Réunion spécialisée de la SGF "Journées Jean Philip", Marseille, 69.

FLÜGEL E. (2004). - Microfacies of carbonate rocks. Analysis, Interpretation and application. - Springer, Heidelberg, 976p.

Haq B.U. \& Al-QAhtani A.M. (2005). - Phanerozoic cycles of sea-level change on the Arabian platform. - GeoArabia, 2, 127-160.

Gradstein F.M. (2004). - A new geological time scale, with special reference to Precambrian and Neogene. - Episodes, 2, 83-100.

Hanini A., Zagrarni M.F., Negra M.H. \& Handoura M. (2004). - The Cenomanian-Turonian Bahloul Formation in Central-North Tunisia. Biosedimentary events and hydrocarbon signification. Proceedings of the $9^{\text {th }}$ Tunisia Petroleum Exploration \& Production Conference, Tunis, 73-83.

Hardenbol J., Thierry J., Farley M., Jacquin T., De Graciansky P.C. \& VAIL P.R. (1998). - Chart 5 of Mesozoic and Cenozoic sequence chronostratigraphic framework of European basins Cretaceous sequence chronostratigraphy. In: P.C. De Graciansky, J. HARDENBol, T. JACQUin \& P.R. VAIL, Eds., Mesozoic and Cenozoic sequence stratigraphy of European basins. - SEPM, sp. Publ. 60, 764-765

Jarvis I., Gale A.S., Jenkys H.C. \& Pearce M.A. (2006). - Secular variation in Late Cretaceous carbon isotopes: a new $\delta^{13} \mathrm{C}$ carbonate reference curve for the Cenomanian-Turonian (99.6-70.6 Ma). Geol. Mag,. 143, 561-608.
Keller G., Han Q., Adatte T. \& Burns S.J. (2001). - Palaeoenvironment of the Cenomanian-Turonian transition at Eastbourne, England. Cret. Res., 22, 391-422.

Lapparent J. (1923). - Leçons de pétrographie. - Masson, Paris, 1.

Layeb M., Jouirou M. \& Belayouni H. (2001). - Signification du contenu argileux de la formation Bahloul. - Notes du Service Géologique de Tunisie, 67, 5-12.

Leckie R. M., Bralower T.J. \& Cashman R. (2002). - Oceanic anoxic events and plankton evolution: Biotic response to tectonic forcing during the mid-Cretaceous. - Paleoceanography, 3, 13-24.

Maamouri A.L., Zaghbib-Turki D., Matmati M.F., Chikhaoui M. \& Salaj J. (1994). - La formation Bahloul en Tunisie centro-septentrionale: variations latérales, nouvelle datation et nouvelle interprétation en terme de stratigraphie séquentielle. - J. Afr. Earth Sci., 18, 37-50.

Molina J.M., Ruiz-OrTiz P.A. \& Vera J.A. (1997). - Calcareous tempestites in pelagic facies (Jurassic, Betic cordilleras, southern Spain. - Sediment. Geol., 109, 95-109.

Naïli H., Belhadj Z., Robaszynski F. \& Caron M. (1995). - Présence de roches mère à faciès Bahloul vers la limite Cénomanien-Turonien dans la région de Tébessa (Algérie orientale). - Notes du Service Géologique de Tunisie, 61, 1-12.

Navarro V., Molina J.M. \& Ruiz-Ortiz P.A. (2009). - Filament lumachelle on top of Middle Jurassic oolite limestones: event deposits marking the drowning of a Tethysian carbonate platform (Subbetic, southern Spain). - Facies, 55, 89-102.

Nederbragt A.J. \& Fiorentino A. (1999). - Stratigraphy and palaeoceanography of the Cenomanian-Turonian boundary event in Oued Mellegue, northwestern Tunisia. - Cret. Res., 20, 47-62.

Razgallah S., Philip J., Thomel G., Zaghbib-Turki D., Chaabani F., Ben Haj Ali N. \& M'Rabet A. (1994). - La limite Cénomanien-Turonien en Tunisie centrale et méridionale: biostratigraphie et paléoenvironnements. - Cret. Res., 15, 507-533.

Rivas P., Aguirre J. \& Braga J.C. (1997). - Entolium beds: Hiatal shell concentrations in starved pelagic settings Middle Liassic, SE Spain. - Eclogae geol. Helv., 90, 293-301.

Robaszynski F., Caron M., Amédro F., Dupuis C., Hardenbol J., GonzaLez Donoso J.M., Linares D. \& Gartner S. (1994). - Le Cénomanien de la région de Kalaat Senan (Tunisie centrale). Litho-, biostratigraphie et interprétation séquentielle. - Rev. Paléobiol., Genève, 12, 351-505.

Sharland P.R., Casey D.M., Davies R.B., Simmons M.D. \& Sutcliffe O.E. (2004). - Arabian plate sequence stratigraphy. - GeoArabia, 1, 199-214

Snedden J.W. \& LiU C. (2010). - A compilation of Phanerozoic sea-level change, coastal onlaps and recommended sequence designations. Search and Discovery Article 40594.

SRARFI D. (1999). - La formation Bahloul (passage Cénomanien-Turonien) aux Jebel Sekarna et Bargou: Stratigraphie et sédimentologie Tunisie centro-septentrionale. - Master memoir, University of Tunis II.

Van Buchem F.S.P., Razin P., Homewood P.W., Oterdoom W.H. \& PhiliP J. (2002). - Stratigraphic organization of carbonate ramps and organic-rich intrashelf basins: Natih Formation (Middle Cretaceous) of northern Oman. - AAPG Bull., 86, 21-53.

Wan X., Wignall P.B. \& Zhao W. (2003). - The Cenomanian-Turonian extinction and oceanic anoxic event: evidence from southern Tibet. - Palaeogeogr., Palaeclimatol., Palaeoecol., 199, 283-298.

ZAGRARni M.F. (1999). - Sédimentologie, stratigraphie séquentielle et diagenèse des faciès du Crétacé supérieur du Jebel Biréno. Paléogéographies des plates-formes carbonatées du Cénomanien supérieur-Coniacien en Tunisie centrale. - PhD Thesis, University of Tunis II.

Zagrarni M.F., Negra M.H. \& Hanini A. (2008). - Cenomanian-Turonian facies and sequence stratigraphy, Bahloul Formation, Tunisia. Sediment. Geol., 204, 18-35. 